Article

\title{
The role of individual relationship marketing factors in influencing customer retention among microfinance institutions in Kenya
}

\author{
Stella Nyongesa ${ }^{1 *}$, Francis Kibera ${ }^{2}$, and Ruth Kiraka ${ }^{3}$ \\ 1 Strathmore University Business School; snyongesa@strathmore.edu \\ 2 University of Nairobi, School of Business; profkibera@gmail.com \\ 3 Strathmore University Business School; rkiraka@strathmore.edu \\ * Correspondence: snyongesa@strathmore.edu;
}

Received: 9 January 2020; Accepted: 4 June 2020; Published: 9 June 2020.

\begin{abstract}
Organizations seeking a competitive advantage are increasingly embracing relationship marketing programs to manage customer relationships more efficiently. However, despite the deployment of such relationship management programs, customer retention continues to be the greatest challenge facing many organizations. This paper argues that relationship marketing factors - trust, commitment, strong bonds, communication, shared values and keeping promises - each plays a unique role in influencing customer retention, however, the nature of the influence of these individual factors on customer retention moreover in a developing market context has not been empirically investigated much. Relying on social exchange theory and relational market behavior theory, this study sought to determine the relationship between these relational factors and customer retention. Data were collected among 492 customers of Kenya's microfinance sector, using a structured self-administered questionnaire. The association between individual relationship marketing factors and customer retention was tested through simple linear regression analysis. Results showed that among the six relational factors, communication and shared values were the most significant. The study makes a theoretical contribution to the relationship marketing knowledge base by providing empirical evidence on the role of individual relationship marketing factors in predicting customer retention. Marketing practitioners should develop relationship management programs that promote communication effectiveness and shared values.
\end{abstract}

Keywords: relationship marketing; relational factors; customer retention; microfinance institutions.

JEL codes: M3.

\section{Introduction}

Several changes have affected how organizations manage customer relationships in recent years. Increased competition, customers' demand for better quality services, more informed customers who easily defect to competitors offering lower prices, as well as the saturation and maturing of markets have made it more difficult for organizations to retain customers (Alrubaiee \& AlNazer, 2010; Varki \& Wong, 2003). Other trends include globalization, technological advances, firms offering similar products and services thereby providing customers with wide choice options (Myhal, Kang, \& Murphy, 2008). In developing economies, organizations like microfinance institutions (MFIs) are struggling to attract and keep their customers to attain long term sustainability. This is occasioned by the rising intense competition, varying customer expectations, dissatisfied customers, and stringent 
regulatory requirements. Such challenges have led to frequent customers' switching between providers and high customer dropout rates from MFI programs.

Studies investigating the link between relationship marketing and customer retention can be categorized into two - those which investigate relationship marketing and customer retention (e.g Alrubaiee \& Al Nazer, 2010; Oly-Ndubisi, 2007; Ranaweera \& Prabhu, 2003), and those which investigate the individual components of relationship marketing and their link with customer retention (Magasi, 2016; Abtin \& Pouramiri, 2016; Sin et al., 2002; Henning-Thurau et al.,2002; Wetzels et al., 1998). By isolating the individual effect of relationship marketing factors, this could provide powerful insights into where firms, such as microfinance institutions, may invest resources to generate the most results from relationship-building programs. In this paper, we argue that the degree of influence of each of these relationship factors on customer retention is different from their combined influence. This paper, therefore, aims to achieve two objectives. First, is to establish the relationship between six commonly cited relationship marketing factors and customer retention. The second is to determine the combined influence of these factors on customer retention.

The rest of the paper is structured as follows. A review of the literature on relationship marketing, relational factors, and customer retention is discussed next. Then we develop the conceptual framework and present the proposed hypotheses the study sought to test. The methods section comes next in which we discuss the research design adopted for this research, data collection, and analysis methods used, and the paper winds up with a presentation of findings, conclusions, study implications, and suggested areas for future research.

\section{Literature Review}

This section presents a review of the literature relevant to this study from which the conceptual model is derived. The literature on relationship marketing, relationship marketing factors, and customer retention is reviewed demonstrating how prior researchers have considered these constructs however with the majority of studies differing from the current study in terms of either concept, context, or methodology. Arising from this literature review, the study hypotheses are formulated.

\subsection{Relationship Marketing}

The relationship marketing orientation emerged in the early 1980s, in the fields of services marketing and industrial marketing (Grönroos, 1994). Since then, emphasis by businesses has turned from focusing on transactional marketing to relationship marketing (Sheth and Parvatiyar, 1995). Several definitions of relationship marketing exist showing that this practice has attracted the attention of many researchers (Berry, 1995; Harker, 1999; Grönroos, 2004; Ballantyne, 1997). Although these definitions differ to some degree, they all point to three main characteristics; that relationship marketing is about developing buyer-seller relationships, the relationships are established over a long term period and the relationships are mutually rewarding to all parties.

The success of a firm's relationship marketing efforts is an issue that has been debated by several relationship scholars in the last decades. Notable among these are Sin, Tse, Yau, Lee, and Chow, (2002) who argue that six behavioral components constitute effective relationship marketing namely trust, bonding, communication, shared values, empathy, and reciprocity. Henning-Thurau, Gwinner, and Gremler, (2002) on the other hand, an advance that word of mouth communication is a key relationship outcome factor. On their part, Hunt, Arnett, and Madhavaram, (2006) posit that the success of a firm's relationship marketing program is determined by relational factors - trust, commitment, cooperation, keeping promises, shared values, and communication between the firm and customers. Velnampy and Sivesan (2012) instead demonstrated that bonds, empathy, and reciprocity were the indicators of successful relational exchanges, whereas Aka, Kehinde, and Ogunnaike (2016) conceptualized trust, commitment, communication, and service quality as the major determinants of relationship marketing. From this review, it becomes evident that there are varying views as to what constitutes successful relationship marketing, however as summarized by Hunt et al. (2006), the most commonly suggested indicators of successful relationship marketing efforts are trust, commitment, communication, 
bonding, cooperation, keeping promises and shared values and these were the relationship marketing factors adopted for this study.

\subsubsection{Trust}

Trust refers to the willingness to rely on an exchange partner in whom one has confidence (Morgan \& Hunt, 1994). Trust is said to be an important determinant of successful business relationships because it's a measure of how each party feels they can rely on the other to fulfill their promise or obligation in the exchange (Callaghan et al., 1995, cited in Sin et al., 2002).

\subsubsection{Commitment}

According to Morgan and Hunt (1994), commitment is the belief by an exchange partner that an ongoing relationship is so valuable that maximum effort is put in to maintain it; on the other hand, Oly Ndubisi, (2007) asserts that it is the enduring desire to maintain a valued relationship measured by the likelihood of customer loyalty and future purchase frequency.

\subsubsection{Communication}

Regarding relationship building, communication is the formal and informal approach of exchanging and sharing useful information between partners on time (Sin et al., 2002). When communication is shared in time, this fosters trust and assists in resolving disputes together with realigning expectations between the parties of exchange. Timely communication assists parties of exchange to respond to opportunities and threats faster hence attain competitive advantages.

\subsubsection{Bonding}

Bonding, another relationship marketing factor, is where the buyer and seller act in a unified manner towards a common goal (Sin et al., 2002). Strong bonds, which may be social, financial, or structural, tend to exist between partners of exchange when they have social interactions, closeness, friendship, feelings of affection, sense of belonging and realize performance satisfaction (EAC, 1993, cited in Sin et al., 2002).

\subsubsection{Keeping Promises}

Gronroos (1990) reasoned that the foundation of developing successful buyer-seller relationships lies in both parties keeping their promises. According to the author, if a firm consistently fulfills its promises to customers, this creates a sense of trust and eventually loyalty. However, to achieve this entails first making realistic promises, then keeping these promises and finally enabling employees to deliver on these promises through training and use of support service delivery systems.

\subsubsection{Shared Values}

Shared values refer to the extent to which partners in exchange have common beliefs concerning behavior, goals, and policies (Morgan \& Hunt, 1994). The authors argue that since marketing is about the exchange of resources, then the parties of exchange need to share common values to build successful buyer-seller relationships. Sin et al., (2002) also theorize that when exchange partners have common goals or values, their commitment to the relationship is strengthened.

\subsection{Customer Retention}

A key cornerstone of business survival is to retain customers for the long term. To achieve this goal, relationship marketing strategies are often employed by businesses to enhance customer retention levels. However, while it is easier for firms to attract new customers, it is often harder to retain these customers (Ryals \& Payne, 2001). Several researchers have demonstrated a positive link between relationship marketing and customer retention and loyalty (Berry, 1983; Morgan \& Hunt, 
1994; Sin, Tse, Yau, Lee \& Chow, 2002; Oly-Ndubisi, 2007). Benefits commonly associated with successful relational exchanges include more satisfied customers, customer loyalty, and increased customer retention (Alrubaiee \& Al-Nazer, 2010; Jagdish \& Parvatiyar, 1995). Others include more revenue, reduced maintenance costs, positive word of mouth communication, customer behavior benefits, financial benefits, social benefits, and consequently customer lifetime profitability (Ryals \& Payne, 2001). Given this, it can be argued that the continued survival of a commercial oriented business depends on its ability to develop meaningful relationships with customers, retain them which consequently leads to an increase in a firm's profits. Reichheld and Sasser (1990) pioneered work in these areas by demonstrating that customer retention has a powerful impact on a firm's bottom line. Also, retaining customers has been found to bring about less operational costs, less price-sensitive customers, lower relationship maintenance costs, and consequently better financial performance (Churchill \& Halpern, 2001; Ang \& Buttle, 2006).

\subsection{Relational Marketing Factors and Customer Retention}

Studies that have investigated the association between individual relationship marketing components (trust, commitment, bonding, communication, keeping promises and shared values) and customer retention, show a variation in the strength of the relationship when each of these components is analyzed. Morgan and Hunt (1994) found communication has a positive and indirect impact, OlyNdubisi (2007) found trust, commitment, communication, and conflict handling were all significant while Sin et al. (2002) found the relationship (trust, bonding, communication, shared values, empathy, and reciprocity) on performance (sales, growth, customer retention, market share, return on investment) positive and significant. HenningThurau et al. (2002) found word of mouth communication is a key relationship outcome factor, Wetzels et al. (1998) instead investigated the role of commitment in service relationships and found that affective commitment has the strongest effect on customers' intention to stay in the relationship and consequently on future revenue streams. Such empirical evidence suggests that relationship marketing efforts characterized by either winning the trust of customers, delivering effective communication, keeping promises, the commitment by customers to the organization, sharing common values, or developing strong buyer-seller bonds are an ideal way for organizations to achieve higher customer retention levels. However, we argue that all these relational factors do not necessarily lead to the same customer retention outcomes. Certain relational factors may be more effective than others depending on the customers' experiences as well as the contextual environment of a business's operations. An analysis of the effect of each of these six relational factors on customer retention in one research has not been addressed much in relationship marketing literature.

Though earlier studies found a positive relationship between relationship marketing and customer retention, the nature of the interaction of the individual relational factors is not yet conclusive due to the varying perspectives and areas of concentration of these previous studies. Moreover, contextually, most studies on relationship marketing and customer retention are based on markets in developed countries (DCs) with few studies available on less developing countries (LDCs) like Kenya yet the market characteristics and consumer behavior patterns of customers in DCs and LDCs differ. Furthermore, the majority of prior studies are in sectors other than the microfinance sector yet this sector is of economic significance to Kenya's poverty eradication agenda hence understanding how to retain customers is crucial to this sector's long term sustainability. In this study, we sought to address these knowledge gaps by investigating the nature of the association between the relational factors and customer retention within Kenya's microfinance sector. Based on this, we postulate that each of these relational factors has a different effect on customer retention which leads us to formulate the hypotheses that:

H1: There is a statistically significant association between each of the relationship marketing factors (trust, commitment, communication, bonding, keeping a promise and shared values) on customer retention; 
H2: The combined influence of the relationship factors on customer retention is different from their influence.

Using existing theoretical and empirical literature we develop a conceptual model (Figure 1) showing the hypothesized relationship between relationship marketing factors (independent variables) and customer retention (dependent variable).

Figure 1. Conceptual Model

Independent variable

(Relationship Marketing)

\section{Dependent Variable \\ (Customer Retention)}

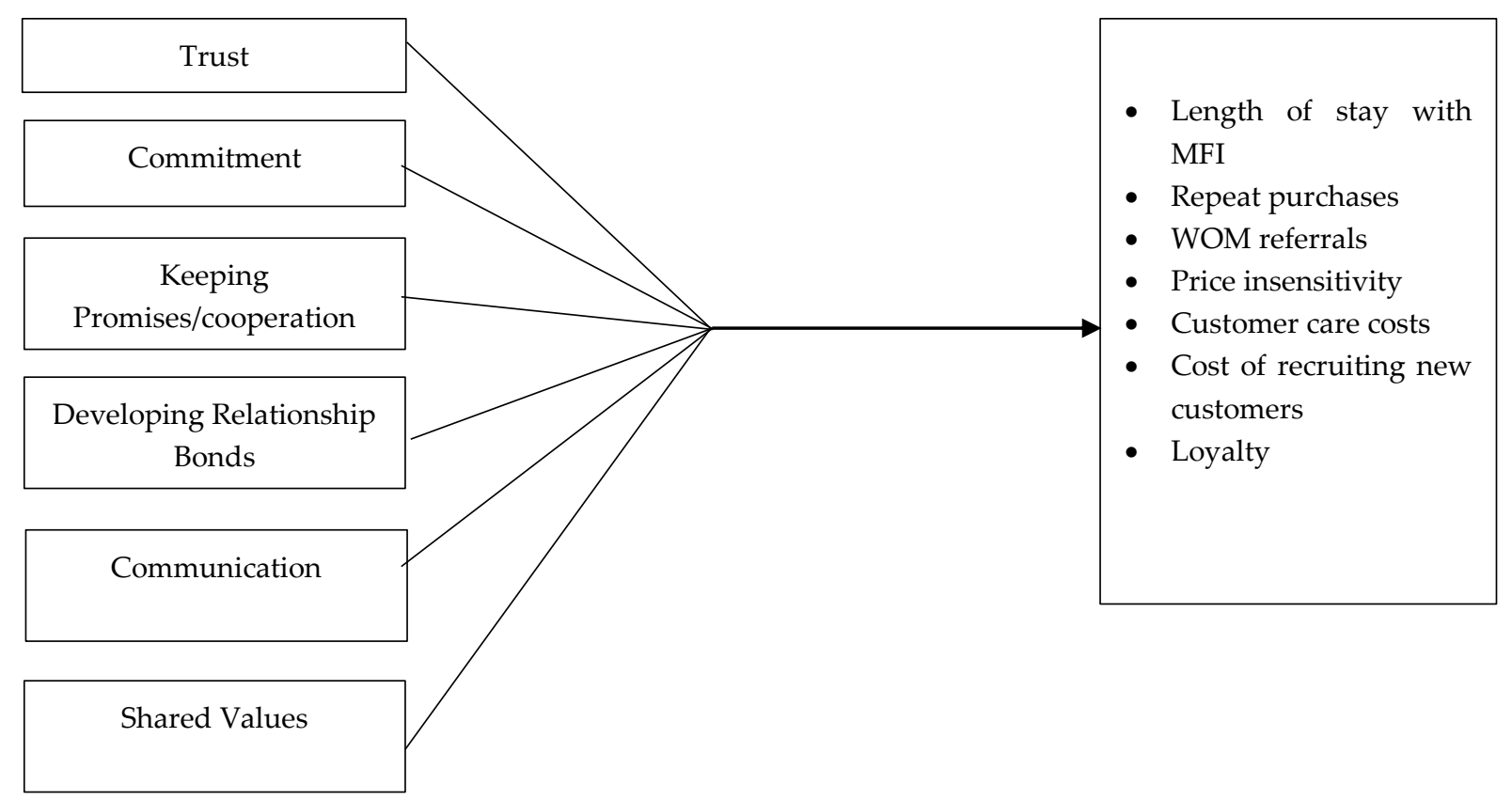

Source: Researchers, 2017

\section{Data and Methods}

\subsection{Data}

A descriptive cross-sectional survey design was adopted because the study sought to establish the direction and strength of relationships between the study variables (Cooper \& Schindler 2006). The population was drawn from fifty-five microfinance institutions in Kenya who were members of the Association of Microfinance Institutions (AMFI). The total customer base for these institutions stood at 41,007 based on the association of microfinance institutions in Kenya (2016) Report. Convenience sampling was used to select customer respondents. Primary data was collected from customers of MFIs using self-administered structured questionnaires. Customers who participated in the study were accessed through the respective institutions' Field marketing officers during the weekly group meetings held with customers. Questionnaires items were developed based on existing literature (Morgan \& Hunt, 1994, Wetzels et al., (1998), Oly Ndubisi (2007), Sin et al., (2002), and Leverin \& Lijander, (2006). The questions were framed as a five-point Likert scale type ranging from not at all (1) to a very large extent (5); or strongly disagree (1) to strongly agree (5). The targeted sample size from whom data was collected was 554 and this was calculated based on the formula for the finite population proposed by Yamane, (1967) cited in Israel, (1992). Responses however were received from 492 customers representing a response rate of $88.8 \%$. 


\subsection{Methods}

To assess the quality of the measures used to obtain data, reliability, and validity tests were carried out through a pilot test using 10 customers who were requested to report on any ambiguous questions, identify any defects in the questions or lack of clarity in the instructions as well as suggest any changes. The internal consistency Cronbach's Alpha $(\alpha)$, which ranges from 0 to 1 , was used to measure how well the measurement items correlate to one another (reliability). Cooper and Schindler (2006) suggest a range of 0.7 to 0.9 , and hence this study adopted a cut off Cronbach value of 0.7. The study variables met the reliability test (Relationship marketing $(\alpha)$ at 0.782 and Customer retention $(\alpha)$ at 0.763 ). Also, face-to-face and content validity were tested to determine the extent to which the instruments were accurate and meaningful. Following data collection, data obtained was first cleaned by discarding incomplete or inconsistently answered questionnaires while extreme values were removed. The remaining questionnaires then underwent coding and analysis using SPSS version 17. Descriptive analysis was performed by summarizing distributions and describing the set of data on factors of the study through producing frequency distributions, mean scores, standard deviations, and coefficients of variation. Inferential analysis was also performed to establish the nature and magnitude of the relationships between the variables and to test the hypothesized relationships, through Pearson's Product Moment Correlation (PPMC), Coefficient of determination (R2), and Simple linear regressions. P-value was used to check for the significance of individual variables in the regression equations, whereby a relationship was considered to be statistically significant if the $p$-value was $\leq$ 0.05 . The general regression model was expressed as $Y=\beta 0+\beta 1 R M+\varepsilon$ Where: $y=$ Customer retention, $\beta 0=$ Constant, $\mathrm{RM}=$ Relationship marketing and $\varepsilon=$ error term.

\section{Results and Discussion}

\subsection{Descriptive Analysis and Results}

Data analysis was first carried out at a descriptive statistical level to determine the demographic profiles of respondents using frequencies and percentages. Besides, descriptive statistics (mean scores, standard deviation, and coefficient of variation) were obtained on respondents' perceptions of relationship marketing and customer retention. The first part of the questionnaire sought customers' demographic profiles. We found a gender balance among respondents who participated in the study with males $(50.60 \%)$ and female (49.40) implying that both male and female customers utilize microfinance services. The finding however seems surprising since it is contrary to the widely held view that microfinance services are mainly utilized by women. The majority $(67.6 \%)$ of respondents were between 35-39 years old with the majority of sampled customers (59.54\%) holding a diploma as the highest level of education. This finding is consistent with the nature of the characteristics of microfinance clients who often are low-income people and possess lower education levels. Concerning the length of stay with the microfinance institutions, the majority $(74.27 \%)$ indicated they had been with the institution for between 1-3 years. Furthermore, the majority of respondents (59.57\%) learned about their institution through referrals from friends, with only a few $(18.25 \%)$ stating that it was through the institutions' marketing programs. According to scholars such as John and Kijboonchoo (2017); Henning-Thurau et al. (2002) and Hunt, Arnett, and Madhavaram (2006), the power of word of mouth communication in bringing about additional customers, especially in service businesses, should not be underestimated.

The next part of the questionnaire sought customers' opinions on the extent to which they trusted their microfinance institution, the institution's level of commitment to them, communication efforts, the strength of relationship bonds, keeping of promises and the extent to which they believed they shared values with their institution. The results were analyzed by obtaining mean scores, standard deviation, and coefficient of variation on each of the Likert scale statements ranging from 1(strongly disagree) to 5 (strongly agree). The results were as presented in Table 1. 
Table 1. Descriptive Summary of Study Variables

\begin{tabular}{cccc|c|c}
\hline & & N & Mean & Std. Deviation & CV (\%) \\
\hline RM(customers) & Trust & 492 & 3.965 & 1.086 & 27 \\
\cline { 2 - 6 } & Commitment & 492 & 3.359 & 1.390 & 42 \\
\cline { 2 - 6 } & Communication & 492 & 3.421 & 1.013 & 31 \\
\cline { 2 - 6 } & Keeping promises & 492 & 3.802 & 1.223 & 32 \\
\hline \multirow{2}{*}{$\begin{array}{c}\text { Customer } \\
\text { Retention }\end{array}$} & Relationship bonds & 492 & 3.373 & 1.278 & 38 \\
\hline & Shared values & 492 & 3.567 & 1.348 & 37 \\
\hline & MEAN SCORE & 492 & 3.581 & 1.223 & 37 \\
\hline
\end{tabular}

Source: Primary Data

Results show trust had the highest overall mean score $($ mean $=3.96)$ followed by keeping promises $($ mean $=3.80)$ implying that most customers of MFIs agreed to a larger extent than their institutions were trustworthy and kept their promises, however, most customers moderately agreed that they would stay committed to their institution (mean=3.3). The overall mean score for relationship marketing was mean $=3.581, \mathrm{SD}=1.223$, and $\mathrm{CV}=34 \%$. Customers' perception therefore on how strong the relationship they had with their institutions was found moderate. Customer retention perceptions on the other hand registered a mean of $3.243, \mathrm{SD}=1.18$, and $\mathrm{CV}=37 \%$. However, on being asked how likely they were to terminate their relationship with the MFI they belonged to, the majority of customers agreed that this was highly likely although there were varied opinions on this issue shown by the high $\mathrm{CV}$ at $64 \%$. These results imply microfinance institutions need to work harder to retain their customers over a long term period.

\subsection{Hypotheses Testing Results}

To test our hypotheses, we performed correlations and regression analyses. The hypotheses were tested at a 95 percent confidence level $(\alpha=0.05)$ with the decision to accept a hypothesis based on $p<0.05$. The correlation coefficient $(R)$, coefficient of determinations $\left(R^{2}\right)$, F-statistic values $(F)$, and beta values $(\beta) . \mathrm{R}^{2}$ was also used to provide an interpretation of the results. Hypothesis $\mathrm{H} 1$ was tested through simple linear regression analysis and these results were as presented in Table 2.

We found a relatively moderate but statistically significant association between the relationship marketing factors and customer retention $(\mathrm{R}=0.471 ; \mathrm{F}=0.855, \mathrm{P}<0.05)$. The coefficient of determination $\left(\mathrm{R}^{2}=0.222\right)$ suggests that relationship marketing factors explain $22.2 \%$ of the variation in customer retention and hence $77.8 \%$ of these variations may be explained by other variables that were not considered in this study. Concerning each relationship marketing factor, the results show statistical significance for all of them ( $\mathrm{p}$-value $<0.05$ ), with communication and shared values being the most significant, followed by commitment, keeping promises, relationship bonds, and trust respectively. Hypothesis 1 was thus supported.

We tested H2: The combined influence of the relationship factors on customer retention is different from their influence through simple linear regression too and using a composite index of the relationship marketing factors. The results are presented in Table 3.

The regression results indicate a significant relationship between overall relationship marketing and customer retention $\left(R=0.453\right.$ and $\left.R^{2}=0.205\right)$, suggesting a moderate and positive association with $20.5 \%$ of the variation in customer retention being explained by relationship marketing programs. This is a slightly lower value in comparison to that obtained when individual factors were considered $(22.2 \%)$. Furthermore, the beta coefficient suggest that a unit increase in relationship marketing will lead to a change in customer retention by 0.266 units, a lower change than that observed for three of the individual relationship factors (shared values, communication, commitment and keeping 
promises) whose beta coefficients were all above $27 \%$. Hypothesis 2 is thus also supported. Hence the regression equation depicting this relationship is fitted as $\mathrm{Y}=3.147+0.266 \mathrm{RM}$.

Table 2. Individual Effect of Relationship Marketing Factors on Customer Retention

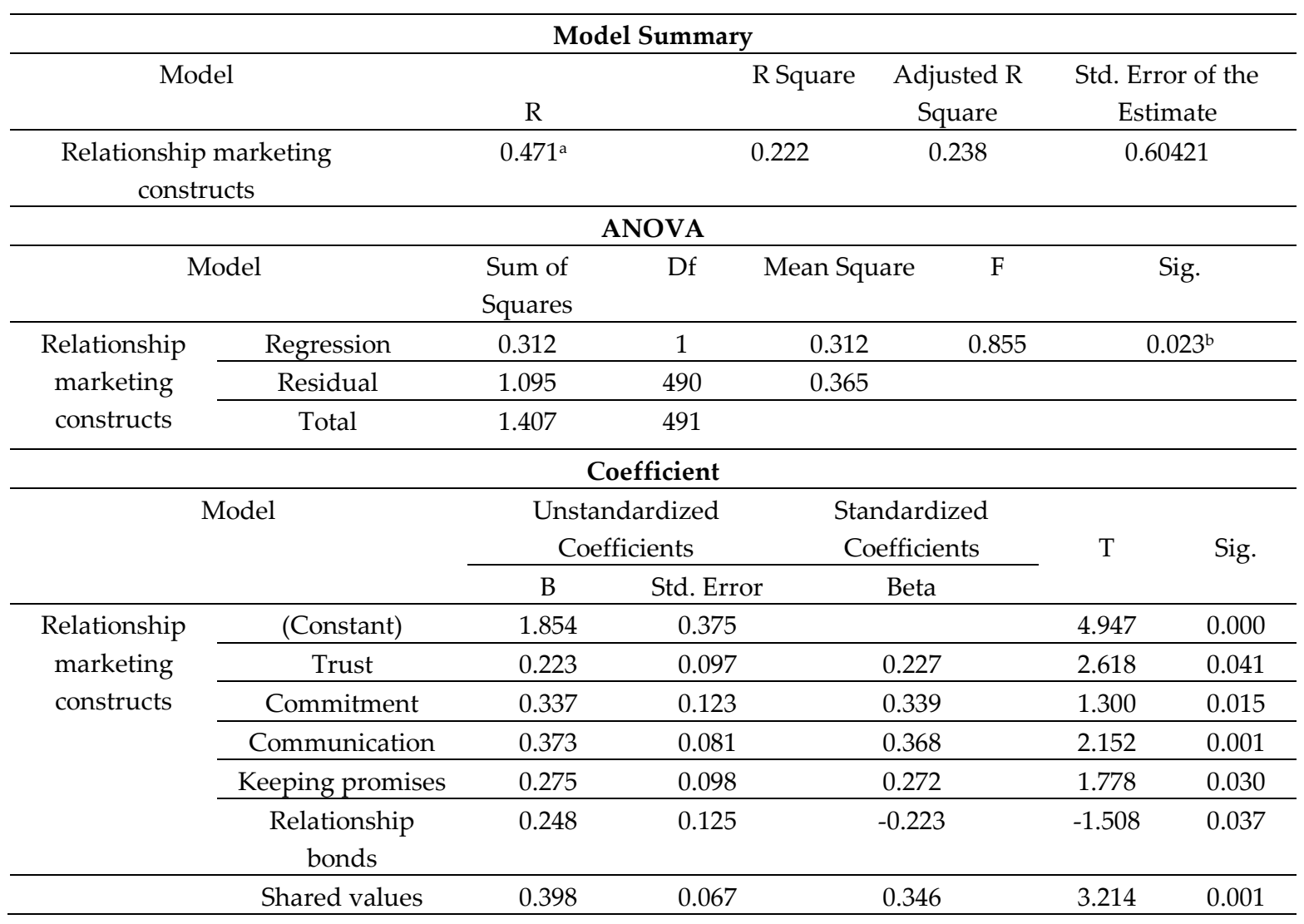

Dependent Variable: Customer retention; Predictors: (Constant), trust, commitment, communication, keeping promises, relationship bonds, and shared values. Source: Primary Data.

\section{Conclusions}

Extant literature has reported a strong association between relationship marketing and customer retention. Consequently, relationship marketing is considered to be a key strategy for retaining customers. The first objective of this study was to establish the association between relationship marketing factors (trust, commitment, communication, bonds, shared values, keeping promises) on customer retention, while the second objective sought to determine the overall influence of relationship marketing on customer retention. The descriptive statistical summary showed trust had the highest overall mean score followed by keeping promises while the inferential results revealed a statistical significance for all the relationship marketing factors, though shared values and communication had the greatest effect.

These findings, therefore, suggest that communication and shared values play a more significant role in retaining customers among microfinance institutions in Kenya implying that if communication between the institutions and their customers is effective, coupled with sharing common beliefs, this may boost customer retention. Although the finding on shared values being one of the most significant has not previously been described, the result on communication is supported by previous research (John \& Kijboonchoo, 2017; Henning-Thurau et al., 2002; Ibok \& Udofot, 2012; and Rootman, Tait, \& Sharp, 2012; Magasi, 2016). These results however differ from some other studies where instead trust, was found to the most to be the most significant (Mazhari et al. 2012; Morgan \& Hunt, 1994; OlyNdubisi, 2007; Abtin \& Pouramiri, 2016). The present results further corroborate the findings of several previous researchers who found that overall, relationship marketing has a strong influence on 
customer retention (Alrubaiee \& Al Nazer, 2010; Oly-Ndubisi, 2007; Ranaweera \& Prabhu, 2003). Therefore, organizations that invest in relationship building efforts and practices characterized by trust, commitment, communication, keeping promises, and shared values, will be in a better position to realize profitable business-customer relationships better than firms that overlook such relationship marketing practices.

Table 3. Relationship Marketing and Customer Retention

\begin{tabular}{|c|c|c|c|c|c|c|c|}
\hline \multicolumn{8}{|c|}{ Model Survey } \\
\hline Model & $\mathrm{R}$ & \multicolumn{2}{|l|}{ R Square } & Adjusted R Square & \multicolumn{3}{|c|}{ Std. Error of the Estimate } \\
\hline $\begin{array}{c}\text { Relationship } \\
\text { marketing }\end{array}$ & $0.453^{\mathrm{a}}$ & \multicolumn{2}{|l|}{0.205} & 0.200 & \multicolumn{3}{|c|}{0.54617} \\
\hline \multicolumn{8}{|c|}{ ANOVA } \\
\hline \multicolumn{2}{|c|}{ Model } & Sum of Squares & $\mathrm{Df}$ & Mean Square & & $\mathrm{F}$ & Sig. \\
\hline \multirow{3}{*}{$\begin{array}{l}\text { Relationship } \\
\text { marketing }\end{array}$} & Regression & 12.701 & 1 & 12.701 & 42.5 & & $0.000^{\mathrm{b}}$ \\
\hline & Residual & 49.220 & 490 & 0.298 & & & \\
\hline & Total & 61.921 & 491 & & & & \\
\hline \multicolumn{8}{|c|}{ Combined coefficients } \\
\hline \multirow{2}{*}{\multicolumn{2}{|c|}{ Model }} & Unstandardized & Coefficients & \multicolumn{2}{|c|}{ Standardized Coefficients } & \multirow[t]{2}{*}{$\mathrm{t}$} & \multirow[t]{2}{*}{ Sig. } \\
\hline & & $\mathrm{B}$ & Std. Error & Beta & & & \\
\hline \multicolumn{2}{|c|}{ (Constant) } & 3.147 & 0.143 & & & 22.025 & 0.000 \\
\hline \multicolumn{2}{|c|}{ Relationship marketing } & 0.266 & 0.041 & 0.453 & & 6.525 & 0.000 \\
\hline
\end{tabular}

Dependent Variable: Customer retention; Predictors: (Constant), Relationship marketing

The present study contributes to the knowledge base on relationship marketing by providing further empirical evidence of the individual effect of relationship marketing factors to predict customer retention thus shedding more light on the potential role that each of these factors may play in influencing customer retention. Practically, findings reveal that marketers are better off if they pay greater attention to building relationships characterized by these relational factors for optimum customer retention results. The study however was limited by using a quantitative approach which placed a constraint to obtaining in-depth insights of respondents which could provide deeper meaning to their responses and also, a relatively small population of MFIs was accessible thereby limiting the generalizability of the findings. Future studies could address these limitations

Funding: The study was funded through a research grant by Strathmore University, Kenya.

Acknowledgments: We would like to extend our utmost gratitude to the management of the Association of Microfinance Institutions in Kenya (AMFI) for providing valuable information about the status of Microfinance in Kenya, as well as to the management of Microfinance Institutions for granting permission to collect data from their customers. We also thank the reviewers of JREM for their insightful comments and suggestions that benefited the paper.

\section{References}

Abtin, A., \& Pouramiri, M. (2016). The impact of relationship marketing on customer loyalty enhancement. Case study: Kerman Iran insurance company. Marketing and Branding Research, 3, 41-49.

Aka, O. D., \& Kehinde, J. O., \& Ogunnaike, O. O. (2016). Relationship marketing and customer satisfaction: a conceptual perspective. Binus Business Review, 7(2), 185-190.

Alrubaiee, L., \& Al-Nazer, N. (2010). Investigate the impact of relationship marketing orientation on customer loyalty: The customer's perspective. International Journal of Marketing Studies, 2(1), 155.

Ang, L., \& Buttle, F. (2006). Customer retention management processes: A quantitative study. European Journal of Marketing, 40(1/2), 83-99.

Association of Microfinance Institutions. (2016). Annual report on the microfinance sector in Kenya. Nairobi Press. 
Berry, L. L. (1983). Relationship marketing. In L. L. Berry, G. L. Shostack, \& G. Upah (Eds.), Emerging Perspectives on Services Marketing, 25-28.

Berry, L. L. (1995). Relationship marketing of services--growing interest, emerging perspectives. Journal of the Academy of Marketing Science, 23(4), 236-245.

Churchill, C. F., \& Halpern, S. S. (2001). Building customer loyalty. Project Report, USAID, and CGAP.

Cooper, R.D. \& Schindler, S.P. (2006), Business Research Methods, 9th edition, McGraw Hill.

Grönroos, C. (1994). From marketing mix to relationship marketing: towards a paradigm shift in marketing. Management Decision, 32(2), 4-20.

Grönroos, C. (2004). The relationship marketing process: communication, interaction,

dialogue, value. Journal of Business \& Industrial Marketing, 19(2), 99-113.

Henning-Thurau, T., Gwinner, K. P., \& Gremler, D. D. (2002). Understanding relationship marketing outcomes: an integration of relational benefits and relationship quality. Journal of Service Research, 4(3), 230 - 247.

Harker, M. J. (1999). Relationship marketing defined? An examination of current relationship marketing definitions. Marketing Intelligence and Planning, 17(1), 13-20.

Hunt, S. D., Arnett, D. B., \& Madhavaram, S. (2006). The explanatory foundations of relationship marketing theory. Journal of Business and Industrial Marketing, 21(2), 72-87.

Ibok, N. I., George, E., \& Acha, I. (2012). Customer retention practices of MF banks - Nigeria 2012.pdf. European Journal of Business and Management, 4(14).

Israel, G. D. (1992). Determining the sample size. University of Florida Cooperative Extension Service, Institute of Food and Agriculture Sciences, EDIS. Retrieved from

Jagdish, S., \& Parvatiyar, A. (1995). The evolution of relationship marketing. International Business Review, 4(4), 397-418.

John, J. \& Kijboonchoo, T. (2017). Identifying the association between relationship marketing and customer loyalty at ABC Bank in assumption university campuses: A case study based on the student's point of view.

Leverin, A., \& Liljander, V. (2006). Does relationship marketing improve customer relationship satisfaction and loyalty? International Journal of Bank Marketing, 24 (4), 232 - 251.

Magasi, C. (2016). Customer relationship marketing and its influence on customer retention: a case of the commercial banking industry in Tanzania. Journal of Emerging Issues in Economics, Finance, and Banking, 1(1), 1756-1755.

Mazhari, Y. M., Madahi, A., \& Sukati, I. (2012). The effect of relationship marketing on costumers' loyalty in Iran Sanandaj City Banks. International Journal of Business and Management, 7 (15).

Morgan, R. M., \& Hunt, S. D. (1994). The commitment-trust theory of relationship marketing. Journal of Marketing, $58(3), 20$.

Myhal, K., \& Murphy, J. A. (2008). Retaining customers through relationship quality: a services business marketing case. Journal of Services Marketing, 22(6), 445-453.

Oly Ndubisi, N. (2007). Relationship marketing and customer loyalty. Marketing Intelligence E Planning, 25(1), 98106.

Ranaweera, C., \& Prabhu, J. (2003). The influence of satisfaction, trust, and switching barriers

on customer retention in a continuous purchasing setting. International Journal of Service Industry Management, 14(4), 374-395.

Reichheld, F., \& Sasser, E. W. J. (1990). Zero Defections - Quality comes to Services. Havard Business Review, (September-October 1990).

Rootman, C., Tait, M., \& Sharp, G. (2012). Relationship marketing and customer retention lessons for South African banks. Southern African Business Review, 15(3), 184-206.

Ryals, L., \& Payne, A. (2001). Customer relationship management in financial services: towards informationenabled relationship marketing. Journal of Strategic Marketing, 9(1), 3-27.

Sheth, J. N \& Parvatiyar, A. (1995). The Evolution of relationship marketing. International Business Review, 4 (4), 397-418.

Sheth, J. N., \& Parvatiyar, A. (1995). Relationship marketing in consumer markets: antecedents and consequences. Journal of the Academy of Marketing Science, 23(4), 255-271.

Sin, L. Y. M., Tse, A. C. B., Yau, O. H. M., Lee, J. S. Y., \& Chow, R. (2002). The effect of relationship marketing orientation on business performance in a service-oriented economy. Journal of Services Marketing, 16(7), 656676. 
Varki, S., \& Wong, S. (2003). Consumer involvement in relationship marketing of services. Journal of Service Research, 6(1), 83-91.

Velnampy, V., \& Sivesan, S. (2012). Determinants of customer relationship marketing of mobile services providers in Sri Lanka:-An application of exploratory factor analysis. Industrial Engineering Letters, 2(6), 10-15.

Wetzels, M., de Ruyter, K., \& van Birgelen, M. (1998). Marketing service relationships: the role of commitment. Journal of Business $\mathcal{E}$ Industrial Marketing, 13(4/5), 406-423.

(C) 2020 by the authors. This article is an open-access article distributed under the terms and conditions of the Creative Commons Attribution (CC BY) license (http://creativecommons.org/licenses/by/4.0/). 